\title{
Article \\ High Temperature and Humidity Affect Pollen Viability and Longevity in Olea europaea L.
}

\author{
Maurizio Iovane (D), Aurora Cirillo *, Luigi Gennaro Izzo *(D), Claudio Di Vaio (D) and Giovanna Aronne \\ Department of Agricultural Sciences, University of Naples Federico II, Via Università 100, 80055 Portici, Italy; \\ maurizio.iovane@unina.it (M.I.); claudio.divaio@unina.it (C.D.V.); giovanna.aronne@unina.it (G.A.) \\ * Correspondence: aurora.cirillo@unina.it (A.C.); luigigennaro.izzo@unina.it (L.G.I.)
}

Citation: Iovane, M.; Cirillo, A.; Izzo, L.G.; Di Vaio, C.; Aronne, G. High Temperature and Humidity Affect Pollen Viability and Longevity in Olea europaea L. Agronomy 2022, 12, 1. https://doi.org/10.3390/ agronomy12010001

Academic Editor: Rina Kamenetsky Goldstein

Received: 17 November 2021 Accepted: 17 December 2021 Published: 21 December 2021

Publisher's Note: MDPI stays neutral with regard to jurisdictional claims in published maps and institutional affiliations.

Copyright: (C) 2021 by the authors. Licensee MDPI, Basel, Switzerland. This article is an open access article distributed under the terms and conditions of the Creative Commons Attribution (CC BY) license (https:// creativecommons.org/licenses/by/ $4.0 /)$.

\begin{abstract}
Olea europaea L. is a crop typical of the Mediterranean area that has an important role in economy, society, and culture of this region. Climate change is expected to have significant impact on this crop, which is typically adapted to certain pedo-climatic characteristics of restricted geographic areas. In this scenario, the aim of this study was to evaluate the time-course response of pollen viability to different combinations of temperature and humidity. The study was performed comparing flowering time and pollen functionality of O. europaea from twelve cultivars growing at the same site belonging to the Campania olive collection in Italy. Pollen was incubated at $12{ }^{\circ} \mathrm{C}, 22^{\circ} \mathrm{C}$, and $36{ }^{\circ} \mathrm{C}$ in combination with $50 \% \mathrm{RH}$ or $100 \%$ RH treatments for 5 days. The results highlighted that a drastic loss of pollen viability occurs when pollen is subjected to a combination of high humidity and high temperature, whereas 50\% RH had less impact on pollen thermotolerance, because most cultivars preserved a high pollen viability over time. In the ongoing climate change scenario, it is critical to assess the effect of increasing temperatures on sensitive reproductive traits such as pollen viability to predict possible reduction in crop yield. Moreover, the results highlighted that the effect of temperature increase on pollen thermotolerance should be evaluated in combination with other environmental factors such as humidity conditions. The screening of olive cultivars based on pollen thermotolerance is critical in the ongoing climate change scenario, especially considering that the economic value of this species relies on successful fertilization and embryo development, and also that production cycle of Olea europaea can be longer than a hundred years.
\end{abstract}

Keywords: climate change; germplasm; olive; pollen viability; pollen functionality

\section{Introduction}

Climate change will severely impact the Mediterranean Basin with an expected rise in temperatures in the range of $2-5{ }^{\circ} \mathrm{C}$ [1-3]. Besides substantial warming, it has been estimated that climate change will result in a significant decrease in precipitation in this region $[3,4]$, which might cause serious economic and ecological changes, influencing plant growth, the attack of pests and weeds, and ultimately, crop yield [5].

The olive (Olea europaea L.) is one of the most characteristic crops of the Mediterranean Basin, having a remarkable economic, social, and cultural impact. This species is widely spread and well adapted to the environmental conditions of the Mediterranean Basin. However, the predicted increase in ambient temperature due to global warming may affect plant physiology, phenology, and reproductive biology of this crop, ultimately reducing its yield $[6,7]$.

The Mediterranean region is characterized by a changeable climate, especially in spring season, when daily temperatures can vary considerably. Moreover, it has been shown that inter-annual climate variations can affect flowering time and pollen production [8]. Indeed, previous studies have shown that the flowering time of O. europaea is highly dependent on yearly spring temperatures, which are rising steadily over time due to global warming $[9,10]$. In this scenario, the olive phenology may provide useful indications to evaluate the influence of climate change on plant growth for the whole Mediterranean 
region, since the geographical limits of this cultivation approximately delimit the extent of the Mediterranean climate in Eurasia and North Africa [11,12]. Since the different olive varieties are adapted to specific climatic, edaphic, and lithological conditions, the possible variations occurring in a climate change scenario would have a significant impact on the distribution of these varieties and, consequently, on their growth and productivity $[13,14]$. This is especially expected for some old varieties cultivated in narrow geographic niches with specific micro-climatic characteristics [15]. Indeed, it has been shown that these varieties exhibit greater vulnerability to both short-term climate variability and long-term climate change [16].

The olive has significant phenotypic and genetic variability [17,18]. Factors including plant longevity, limited selection pressure, and limited replacement with new genotypes have reduced genetic erosion and favored the preservation of genetic diversity of olive varieties [19]. Italy has the richest olive collection, including about 700 different varieties. Among the Italian regions, Campania has one of the largest collections [20,21], and many of these varieties are characterized by an extensive morphological diversity and adaptation to local environmental conditions [22]. Olive plants can produce an abundant number of flowers, but generally, only a small percent (1-2\%) of them set normal fruits that reach maturity $[23,24]$. The success of a flower to become a fruit mainly depends on the pollination and fertilization processes. Previous studies reported that pollen germination and pollen tube growth are sensitive to elevated temperatures [25,26]. Moreover, it has been shown that the combination of relative humidity $(\mathrm{RH})$ and temperature can affect pollen viability of other species [27-29]. Temperature also influences both drupe development and oil composition in olive. For example, in very hot sites, olives can show early pigmentation due to the rapid degradation of chlorophyll due to high temperatures [30], whereas in sites with lower temperatures, olive oil has a high content of unsaturated fatty acids [31]. Temperature can also influence the aromatic components of olive oil, reducing the content of volatile substances [32]. Hence, it is arguable that the growing environment is crucial in expressing the typical characteristics and quality of olive cultivars [33]. In most crop species, including Olea europaea L., the production of fruits and seeds relies on pollen functionality. Since pollen viability and germinability are both essential to ensure fertilization, the interaction of pollen with extreme weather events can significantly limit crops productivity in the current climate change scenario [34]. Among extreme weather events, heat waves during early stages of pollen development can reduce pollen functionality in Solanum lycopersicum L., resulting in a drastic loss of pollen germinability [35].

Most of the studies evaluating the effect of environmental factors on olive pollen mainly focused on temperature $[26,36]$, whereas very few studies evaluated the combined effect of temperature and humidity [37]. Specifically, Koubouris et al. [37] studied the effect of pre-incubation temperature and humidity on olive pollen before in vitro germination. However, authors did not test the combined effect of high temperature and high humidity, which could severely affect pollen functionality. Among protocols to assess pollen functionality, the use of diaminobenzidine (DAB) reaction is an efficient method to assess pollen viability responses towards environmental factors [38,39]. Due to its ease of use, the DAB method can be useful for large screening of pollen viability, such as the case of studies with numerous cultivars. In the current climate change scenario, the aim of this study was to highlight possible differences among different olive cultivars in the time-course response of pollen viability to different combination of temperature and humidity treatments. We used pollen from 12 olive cultivars belonging to germplasm of the Campania region in Southern Italy and growing at the same site. We hypothesized that both temperature and humidity would affect pollen viability with possible changes due to treatment duration and cultivars. Moreover, we hypothesized that high humidity would enhance the negative effect of high temperature on pollen viability and longevity. 


\section{Materials and Methods}

\subsection{Plant Material and Flowering Monitoring}

The experiment was performed using pollen from 12 olive cultivars of Campania region. Plants belong to the open-field collection conserved at "Improsta" Regional Experimental Farm in Eboli (SA) $\left(40^{\circ} 33^{\prime} 29^{\prime \prime} \mathrm{N} ; 4^{\circ} 58^{\prime} 28^{\prime \prime}\right.$ E at 15 m.a.m.s.l.). We selected olive cultivars representative of 4 provinces of Campania region and covering the bioclimatic diversity of the whole area (Table 1).

Table 1. Cultivars of Olea europaea L. from 4 provinces of Campania region in Italy.

\begin{tabular}{ccc}
\hline N & Province & Name \\
\hline 1 & & Marinese \\
2 & Avellino & Ravece \\
3 & & Ogliarola \\
\hline 4 & & Ortice \\
5 & Benevento & Ortolana \\
6 & & Racioppella \\
7 & Caserta & Femminella \\
\hline 8 & & Caiazzana \\
\hline 9 & Salerno & Biancolilla \\
10 & & Carpellese \\
11 & & Pisciottana \\
12 & & Salella \\
\hline
\end{tabular}

For each cultivar, the duration of flowering was determined by a procedure reported by Rapoport and Rallo 1991 [40] with some modifications: the flowering phenology of three different branches with south exposure and approximatively 100 flowers per branch was observed. We considered the first day of flowering to be when $10 \%$ of flowers per each branch were open, and the last day to be when $100 \%$ of flowers per branch were open. The duration of flowering (number of days) was then averaged based on measurements on the three different branches.

In the field, data of minimum, maximum, and medium temperature $\left({ }^{\circ} \mathrm{C}\right)$ and $\mathrm{RH}(\%)$ during May 2021 were recorded from the agro-meteorological regional station of Eboli (SA), located at "Improsta" Regional Experimental Farm.

The collection of pollen samples was carried out from 18 to 28 May 2021. Pollen was shed from the inflorescences in Petri dishes using pollen vibrators. Sampling was performed in the morning, Petri dishes were placed inside a thermal bag at $\sim 5^{\circ} \mathrm{C}$ and transported to the laboratory in few hours. For each cultivar, pollen was collected from branches with north, south, east, and west exposure from three different plants.

\subsection{Temperature and Humidity Treatments}

Pollen samples were incubated under six different combinations of temperature and humidity for a total of 5 days. According to the temperature measured during the flowering season at the experimental farm, three temperature treatments were tested: $12{ }^{\circ} \mathrm{C}, 24^{\circ} \mathrm{C}$, and $36{ }^{\circ} \mathrm{C}$. More specifically, $12{ }^{\circ} \mathrm{C}$ and $24{ }^{\circ} \mathrm{C}$ were tested to simulate the averaged minimum and maximum temperatures of May, whereas $36{ }^{\circ} \mathrm{C}$ was chosen to simulate a possible scenario of global warming and heat waves. In combination with temperature treatments, the pollen from the 12 cultivars was incubated at 50\% $\mathrm{RH}$ and $100 \% \mathrm{RH}$ to simulate the effect of dry-sunny and wet-rainy days occurring during the flowering season.

Temperature treatments were performed using three separated incubators (VELP, FOC $200 \mathrm{IL}$ ) set with $12{ }^{\circ} \mathrm{C}, 24{ }^{\circ} \mathrm{C}, 36^{\circ} \mathrm{C}$, respectively. In each incubator, to achieve $50 \%$ or $100 \%$ $\mathrm{RH}$ conditions, we enclosed the bulk samples of pollen in two separated plastic containers containing: (a) a beaker with $\mathrm{Mg}\left(\mathrm{NO}_{3}\right)_{2}$ saturated solution to reproduce $50 \% \mathrm{RH}$ and (b) wet tissues to achieve $100 \% \mathrm{RH}$. 


\subsection{Analysis of Pollen Viability}

Pollen thermotolerance and longevity of the 12 olive cultivars were assessed, performing viability tests at 1,3 , and 5 days' incubation. Pollen viability was assessed through diaminobenzidine $(\mathrm{DAB})$ reaction $[38,39]$. Each pollen sample was gently collected with a brush from the Petri dish and placed onto $10 \mu \mathrm{L}$ droplet of water on a microscope slide. One droplet of $10 \mu \mathrm{L}$ of DAB reagent was then added on each sample. Successively, the microscope slides were gently warmed on a heating plate (set at $50^{\circ} \mathrm{C}$ ) and mounted with a cover slip. The viability of pollen at sampling $\left(\mathrm{T}_{0}\right)$ was assessed to compare possible differences in initial pollen functionality among cultivars and to have a reference point for comparing the effect of temperature, $\mathrm{RH}$, and their interaction throughout the incubation period. We scored as viable the pollen grains stained black/brown and as not viable the ones that remained faint/colorless. The percentage of pollen viability was measured at different incubation time, counting at least 100 pollen grains per microscope slide on a total amount of 6 slides per cultivar per treatment.

\subsection{Data Analyses}

Data were analyzed using Excel ver. 16 (Microsoft Corp., Redmond, DC, USA) and SPSS Statistics ver. 21 (IBM Corp., Chicago, IL, USA). Percentage data of pollen viability was preliminary converted with arcsine function. Shapiro-Wilk's and Levene's tests were used to assess the normality and homogeneity of variance, respectively. The influence of the different categorical independent variables (i.e., cultivar, time, temperature, and humidity) and their possible interactions on pollen viability were analyzed using the ANOVA. Pairwise comparisons were performed with Tukey's HSD test $(p>0.05)$ to identify differences among treatments and cultivars.

\section{Results}

\subsection{Climatic Parameters}

Temperature and humidity data recorded in May 2021 at the experimental farm are shown in Figure 1. The average values of the daily minimum, medium, and maximum temperature were $11.8^{\circ} \mathrm{C}, 17.7^{\circ} \mathrm{C}$, and $23.3^{\circ} \mathrm{C}$, respectively. The highest temperature was recorded on 24 May, reaching a peak value of $31.8^{\circ} \mathrm{C}$, while the lowest temperature was $7.5^{\circ} \mathrm{C}$ and was recorded on 21 May. On average, the daily minimum, medium, and maximum $\mathrm{RH}$ values were $50.6 \%, 73.1 \%$, and $91.29 \%$, respectively. Overall, the daily RH values were comparable between the different days, except for a considerable decrease in daily RH values that was recorded from 20 May to 25 May (Figure 1).
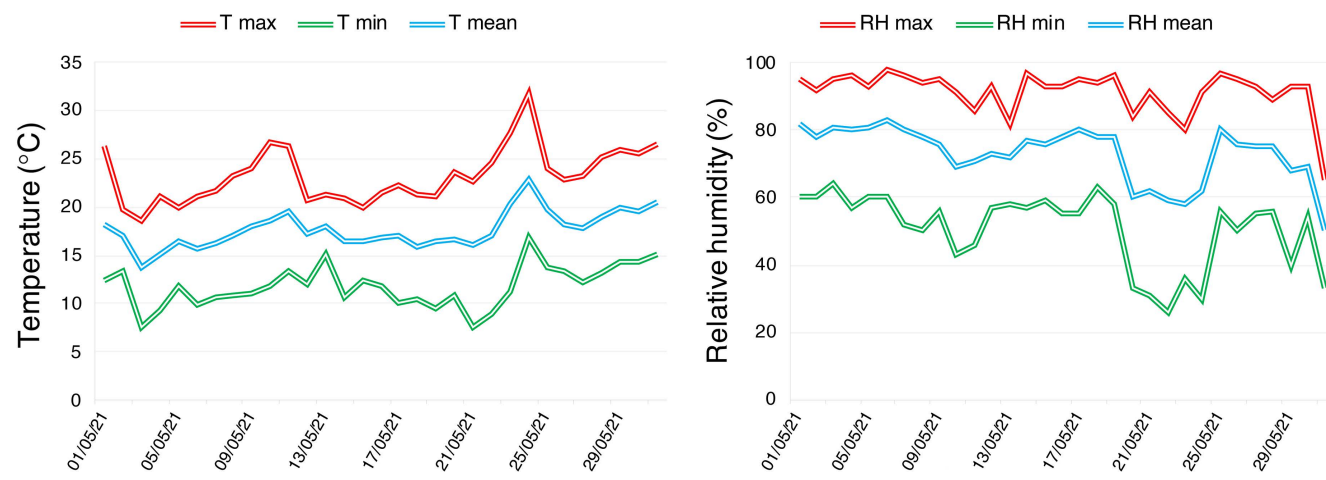

Figure 1. Daily trend of maximum (red line), minimum (green line), and mean (blue line) temperature and humidity measured in May 2021 at "Improsta" Regional Experimental Farm, in Eboli (SA) $\left(40^{\circ} 33^{\prime} 29^{\prime \prime} \mathrm{N} ; 14^{\circ} 58^{\prime} 28^{\prime \prime} \mathrm{E}\right.$, at 15 m.a.s.l.).

\subsection{Flowering Time}

Figure 2 shows the duration of flowering time of the different olive cultivars considered in this study. On average, the flowering time among cultivars was 7 days. Moreover, the 
shortest and the longest duration of flowering were recorded in 'Pisciottana' (3 days) and 'Femminiella' (10 days), respectively (Figure 2).

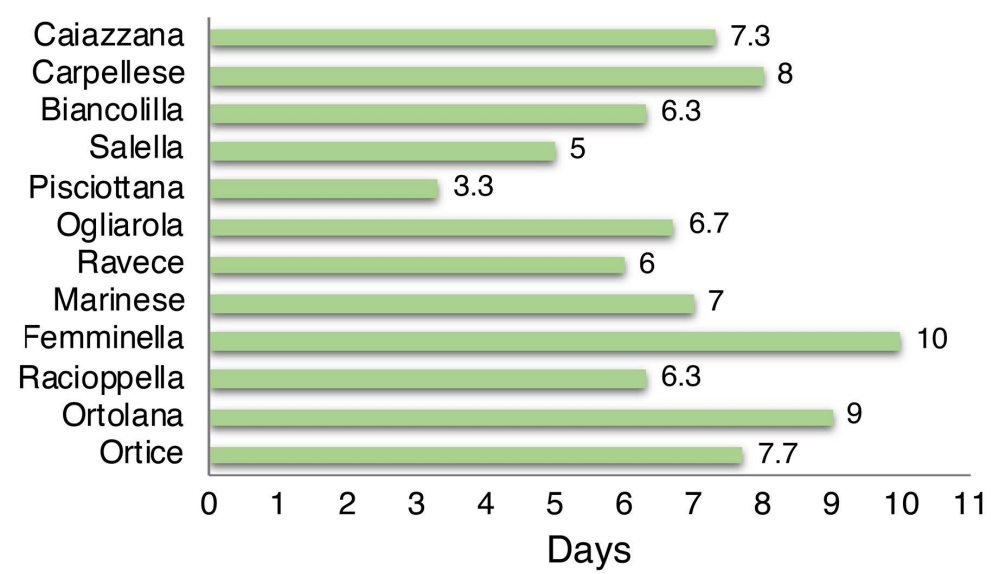

Figure 2. Duration of flowering in 12 olive cultivars from Campania region in Italy.

\subsection{Pollen Viability}

According to the ANOVA, all factors tested in this study (i.e., cultivar, temperature, and humidity) had a significant effect on pollen viability over time (Table 2). The viability tests performed on pollen at $\mathrm{T}_{0}$ showed significant differences between the 12 cultivars (Figure 3). However, despite these differences, pollen viability of all cultivars at $\mathrm{T}_{0}$ ranged between $84 \%$ and $95 \%$, except for 'Marinese', in which pollen viability was $64 \%$.

Table 2. Analysis of variance for the effects of cultivar, relative humidity $(\mathrm{RH})$, temperature, or their interaction on pollen viability of Olea europaea.

\begin{tabular}{ccc}
\hline Factor & Sum of Squares & Sig. \\
\hline Cultivar & $165,808.8$ & $* * *$ \\
Time & $548,079.9$ & $* * *$ \\
RH & $157,134.8$ & $* * *$ \\
Temperature & $28,848.1$ & $* * *$ \\
Temperature $\times$ RH & $27,059.9$ & $* * *$ \\
RH $\times$ Cultivar & 8670.5 & NS \\
Temperature $\times$ Cultivar & $13,972.0$ & NS \\
Temperature $\times$ RH $\times$ Cultivar & $14,478.7$ & NS \\
\hline
\end{tabular}

NS, or ${ }^{* * *}$ indicate nonsignificant or significant at $p<0.001$, respectively.

For each cultivar, the time-course response of pollen viability was affected by the different combinations of temperature and RH over 5 days' incubation. Regarding treatments with $50 \% \mathrm{RH}$, pollen viability showed no significant decrease over time compared to pollen at $\mathrm{T}_{0}$ in all cultivars. Notably, pollen preserved a high viability $(\sim 80 \%)$ both at high $\left(24-36^{\circ} \mathrm{C}\right)$ and low $\left(12{ }^{\circ} \mathrm{C}\right)$ incubation temperature over time (Figure 4$)$. A lower pollen viability was found only in 'Marinese', but it was comparable to pollen viability at $\mathrm{T}_{0}$.

Differently from treatments with $50 \% \mathrm{RH}$, pollen subjected to $100 \% \mathrm{RH}$ showed a significant decrease over time in all cultivars with differences due to the incubation temperature. Overall, the results showed a drastic loss of viability when pollen was subjected to a combined effect of high humidity $(100 \%)$ and high temperature $\left(36^{\circ} \mathrm{C}\right)$. Indeed, pollen grains incubated at $100 \% \mathrm{RH}$ and $36^{\circ} \mathrm{C}$ completely lost their viability after 3 days' incubation in almost all cultivars. Pollen viability was preserved for more than 3 days' incubation at $100 \% \mathrm{RH}$ and $36^{\circ} \mathrm{C}$ only in 'Biancollilla', although with low values $(\sim 20 \%)$ (Figure 4$)$. 


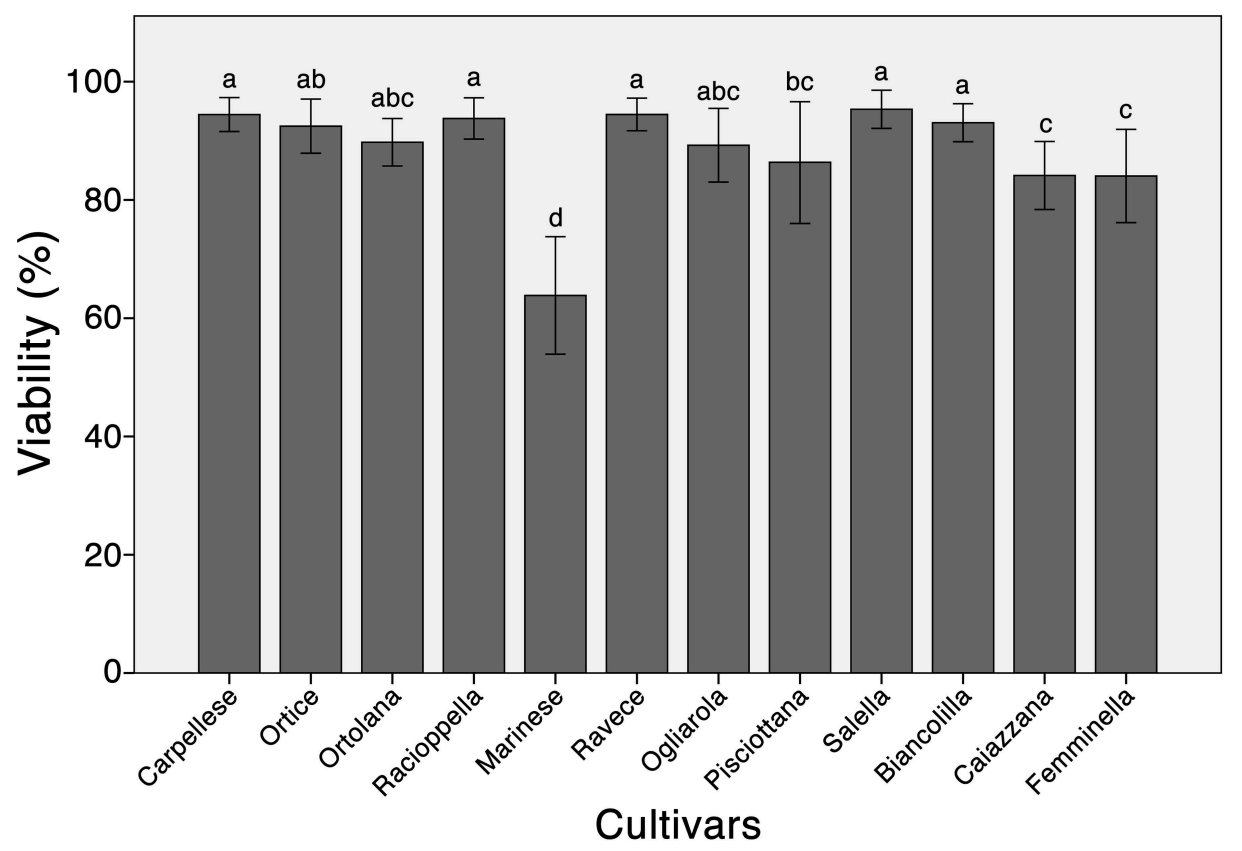

Figure 3. Pollen viability of 12 cultivars of Olea europaea $\mathrm{L}$. at sampling time $\left(\mathrm{T}_{0}\right)$. Letters indicate significant differences between cultivars $(p<0.05)$. Each data point represents the mean $\pm \operatorname{SE}(n=6)$.
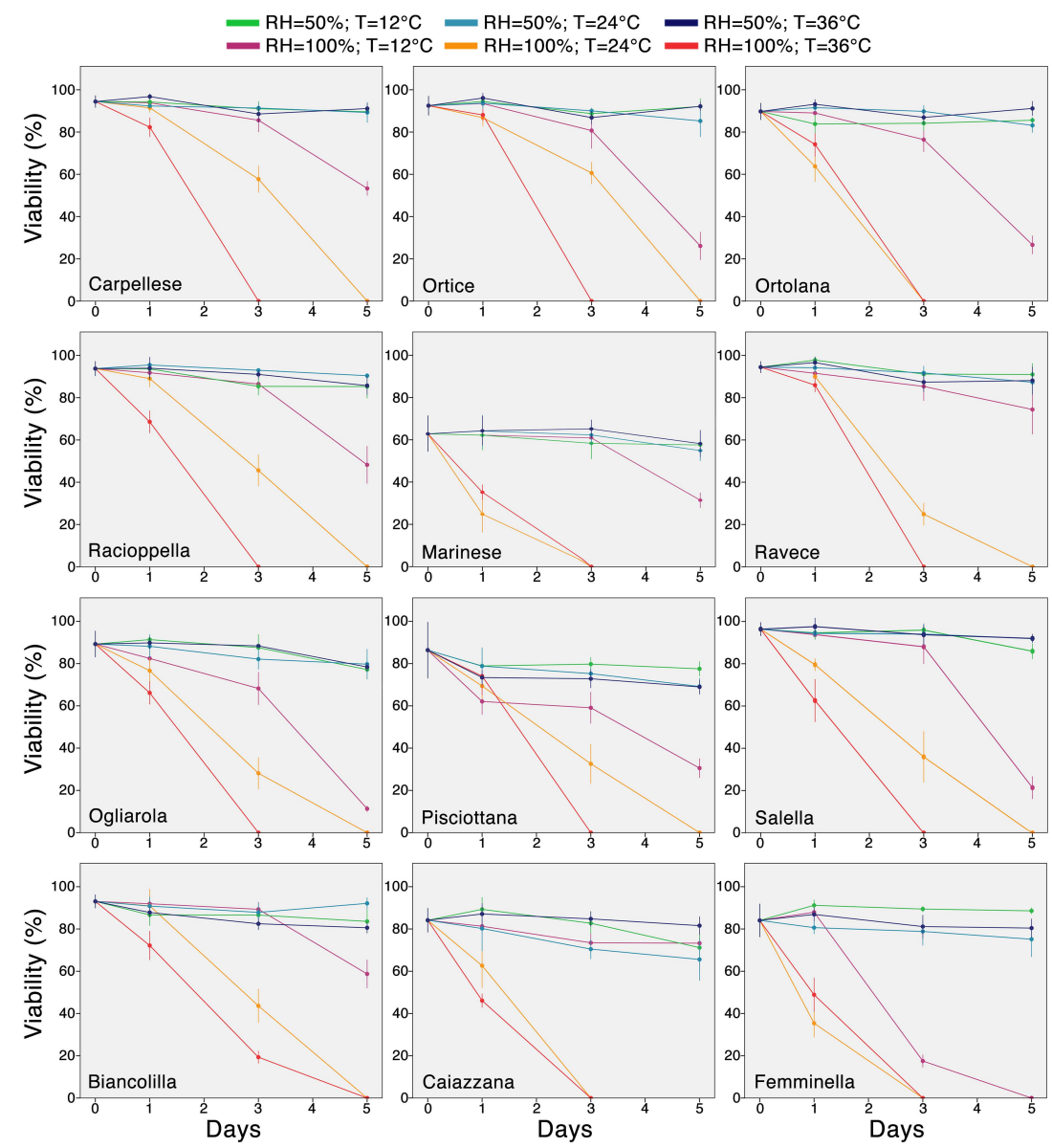

Figure 4. Viability of pollen from 12 olive cultivars incubated at six different combinations of temperature and humidity for 5 days $\left(\mathrm{T}_{1}-\mathrm{T}_{5}\right)$ from sampling $\left(\mathrm{T}_{0}\right)$. Each line shows the mean $\pm \mathrm{SE}$ $(n=6)$. 
A drastic loss of pollen viability also occurred when pollen was subjected to $100 \% \mathrm{RH}$ and $24{ }^{\circ} \mathrm{C}$, showing considerable variability over time depending on the cultivar. Compared to pollen at $100 \% \mathrm{RH}$ and $36{ }^{\circ} \mathrm{C}$, pollen at $24{ }^{\circ} \mathrm{C}$ showed higher viability over time and preserved its viability longer than under $36^{\circ} \mathrm{C}$. Indeed, pollen under $100 \% \mathrm{RH}$ and $24{ }^{\circ} \mathrm{C}$ remained viable for up to 5 days' incubation in most of the cultivars except for 'Marinese', 'Caiazzana', and 'Ortolana', in which pollen grains become unviable at 3 days' incubation (Figure 4).

Differently from $24{ }^{\circ} \mathrm{C}$ and $36^{\circ} \mathrm{C}$, the combination of $100 \% \mathrm{RH}$ and $12{ }^{\circ} \mathrm{C}$ showed a more gradual loss of pollen viability over time in most of the cultivars. More specifically, pollen viability remained high over 3 days' incubation and never decreased below 60\%, except for 'Femminella'. Interestingly, pollen incubated at $100 \% \mathrm{RH}$ and $12{ }^{\circ} \mathrm{C}$ showed no significative difference compared to treatments with $50 \%$ RH up to 3 days' incubation (Figure 4).

\section{Discussion}

\subsection{Climatic Parameters and Flowering}

Recent studies indicate that nearly all European regions will be affected by the impact of climate change $[27,41,42]$. In this scenario, the Campania region in Italy has already experienced an increase in minimum temperatures of approximately $1.4{ }^{\circ} \mathrm{C}$ from 2005 to 2017 [43]. This situation, in agreement with research showing a dramatic global warming since the 1980s [13,44], poses concerns regarding the impact that climate change can have also on restricted geographical areas such as that of the Campania region.

O. europaea is a typical Mediterranean species whose economic production cycle is extremely long, and fruit production relies on pollen efficiency and fertilization success. Therefore, studies on the interaction between flower biology and environmental parameters involved in climate change scenario are relevant.

Our results on flowering period (time and duration) are comparable with those reported for several olive cultivars of the Campania region in the year from 2009 to 2010 [45], who showed that the average duration of flowering was 7 days and occurred during the second half of May. It is known that environmental factors can affect many aspects of inflorescence development, pollination, and fertilization; in particular, high temperatures can influence the timing of phenological phases such as leaf formation and flowering in many species including O. europaea [46-48]. Our data showed that, in the last decade, the flowering time and duration of the olive cultivars considered in this study did not change. However, studies on other species highlighted that short periods of high temperature do not affect flowering phenology but can reduce pollen lifespan so drastically that grains are already dead at the time of anther dehiscence [35]. Indeed, it has been shown that the formation of pollen tetrads and bi-nucleate olive pollen is very sensitive to small increments in temperature in May, when the heat demand for flowering is nearly fulfilled [49]. In addition, besides the satisfaction of heat requirements, it is possible that different olive cultivars require the fulfilment of other conditions for starting the flowering process, such as a mean temperature above $15^{\circ} \mathrm{C}$ during the week before the anthesis [12,49]. It should also be considered that the suitable temperature range for metabolic process in O. europaea is rather narrow, with an optimal temperature interval of approximatively $10^{\circ} \mathrm{C}$ (from $20{ }^{\circ} \mathrm{C}$ to $30{ }^{\circ} \mathrm{C}$ ) [50]. Therefore, when new cultivars are introduced in specific areas, it is critical to consider climatic requirements and flowering time of these cultivars.

\subsection{Pollen Viability}

The response of pollen to environmental factors is critical in O. europaea, considering that self-incompatibility represents a common phenomenon in most of the olive cultivars [51]. Indeed, olive pollen from different cultivars needs to survive along its journey from the stamen to the stigma of different flowers to ensure the formation of seeds and drupes. Considering the great genetic diversity of olive cultivars in the Campania region, 
pollen viability represents a crucial feature for the selection of cultivars to be used as pollen donors in a climate change scenario.

Our results showed that the decrease in pollen viability over time is highly dependent on the exposure to different combinations of temperature and RH. Pollen viability at sampling time exceeded $80 \%$ in almost all cultivars tested in this study. Interestingly, pollen viability of these cultivars was higher compared to most commercial cultivars from Europe, which generally range between $60 \%$ and $70 \%$ [52-54]. The low genetic erosion due to the limited replacement of typical olive cultivars with new genotypes in Campania region may have conserved relevant reproductive traits such as pollen viability. On the other hand, commercial cultivars have mostly been selected to overcome self-incompatibility issues to increase plant productivity [55], but probably overlooking reproductive traits such as pollen viability during breeding programs.

Our results are in agreement with previous studies, showing that high temperatures can reduce pollen viability more than low temperatures $[29,54]$. It has already been reported that temperatures above $22{ }^{\circ} \mathrm{C}$ can reduce by $50 \%$ the initial pollen viability of $O$. europaea in 1-3 days [54]. However, previous studies mostly overlooked the effect of humidity, since $\mathrm{RH}$ was not explicated or fixed, and its effect could not be evaluated. Conversely, our study focused on the effect of different combinations of temperature and humidity to disentangle their effects on pollen functionality. Overall, with this approach, we found that RH has a substantial influence on pollen thermotolerance over time.

Previous studies have shown that the exposure of olive pollen to high RH during preincubation can significantly decrease pollen germinability in vitro at low temperatures [37]. Contrastingly, our results showed that high humidity severely increase pollen sensitivity to both low and high temperatures. Specifically, the combination of high temperature $\left(36^{\circ} \mathrm{C}\right)$ and high $\mathrm{RH}(100 \%)$ significantly reduced pollen viability already after 1 day of exposure, and pollen was completely unviable after 3 days in most of the cultivars. Conversely, pollen exposed to low $\mathrm{RH}(50 \%)$ preserved high viability $(\sim 80 \%)$ both at higher $\left(24-36^{\circ} \mathrm{C}\right)$ and lower $\left(12{ }^{\circ} \mathrm{C}\right)$ incubation temperatures over 5 days. These differences in pollen longevity could be related to specific mechanisms adopted by pollen to survive hostile environmental conditions [56]. Indeed, pollen grains under low humidity environments can enter a state of complete or partial arrest of metabolic processes associated with a high resistance to environmental stresses [56]. This phenomenon might explain the significant differences of pollen thermotolerance to high or low humidity.

Water content of pollen grains generally decrease after flower anthesis and anthers dehiscence when pollen is exposed to the environment [57]. Therefore, from anthesis on, the possibility of pollen to enter in a quiescent state of development and resist to unfavorable temperatures depends on pollen exposure to environmental humidity. Indeed, especially in self-pollinating species, pollen is dispersed in a well-hydrated state and remains metabolically active; this pollen is generally more sensitive to environmental stresses and has reduced viability, since it needs to germinate rapidly upon landing on the stigma of the same flower [58-60]. Contrastingly, in cross-pollinated species such as O. europaea, pollen needs to survive for a relative long time, and therefore, it needs to reduce its water content to maintain a metabolically inactive state during its journey to the stigma of other flowers. In this case, the balance between the content of water, osmolyte compounds, and stabilizing proteins in pollen grains make the cellular content "glassy" and all the metabolic activities slow down [61]. However, this "glassy" state, responsible for increasing pollen longevity, is influenced by both humidity and temperature exposure of pollen grains $[62,63]$. Indeed, when pollen is exposed to low temperatures, this state of glassy cytoplasm can also be achieved in conditions of high humidity, and this would explain why pollen exposed to $12{ }^{\circ} \mathrm{C}$ and $100 \% \mathrm{RH}$ preserved a high viability up to 5 days in most of the cultivars we tested. As regards temperatures of $24^{\circ} \mathrm{C}$ or $36{ }^{\circ} \mathrm{C}$, their negative effects on pollen viability becomes evident over time only when in combination with exposure to high $\mathrm{RH}$. 
Overall, the differences in thermotolerance found between the different olive cultivars can be linked to the capability of pollen in adopting specific strategies to face heat stress including dehydration, accumulation of osmolytes, and synthesis of protective molecules such as heat-shock proteins (HSPs). Numerous studies have highlighted the key role of HSPs in activating heat-stress responses in reproductive cells of several plant species [64-68]. To date, HSPs have been identified in O. europaea but only in vegetative tissues [69]. In the present study, it is likely that the different responses of pollen to temperature and humidity found between cultivars are due to differences in heat-stress response pathways. In this regard, the screening of HSPs gene expression and synthesis of olive cultivars would provide a better understanding of the molecular mechanisms adopted by pollen to cope with heat stress. Moreover, such insights could be useful to select suitable olive cultivars as pollen donor to be used in a climate change scenario.

\section{Conclusions}

Despite the increase in temperature in Campania region over the last decade, no significant change in flowering time of O. europaea was found compared to previous studies. However, a drastic loss of pollen viability was found under high temperature and humidity conditions. Overall, the decreasing trend of pollen viability under the different combinations of temperature and humidity was comparable between cultivars, except for few cases. Specifically, most of the olive cultivars showed a significant decrease of pollen viability already after $24 \mathrm{~h}$ incubation under $36{ }^{\circ} \mathrm{C}$ and $100 \% \mathrm{RH}$, and a complete loss of viability after 3 days' incubation in the same conditions. Interestingly, pollen exposed to low RH (50\%) preserved high viability both at high and low incubation temperatures over 5 days, indicating that pollen thermotolerance is affected by humidity conditions. In a current scenario of climate change, it is critical to evaluate the effect of temperature on reproductive traits to predict the future impact of global warming on crop yield; on the basis of the results obtained, we could therefore state that the cultivars that showed greater tolerance to extreme temperatures and humidity was Biancolilla ( $\mathrm{RH} 100 \%-\mathrm{T}^{\circ}$ $36{ }^{\circ} \mathrm{C}$ ), while 'Carpellese', 'Ortice', 'Racioppella', 'Ravece', 'Ogliarola', 'Pisciottana', and 'Salella' also showed good tolerance in conditions of $\mathrm{RH} 100 \%$ and $\mathrm{T}^{\circ} 24{ }^{\circ} \mathrm{C}$. However, it becomes evident that other environmental factors such as humidity must be considered when evaluating pollen thermotolerance. Moreover, considering the key role of the heatshock proteins in heat-stress responses, further studies must investigate the molecular mechanism adopted by olive pollen to cope with environmental stresses.

Author Contributions: Conceptualization, G.A. and C.D.V.; methodology, G.A., C.D.V., M.I. and L.G.I.; software, M.I., L.G.I. and A.C.; formal analysis, M.I., L.G.I. and A.C.; investigation, M.I., L.G.I. and A.C.; resources, G.A and C.D.V.; data curation, M.I., L.G.I. and A.C.; writing-original draft preparation, M.I. and A.C.; writing-review and editing, L.G.I., G.A. and C.D.V.; visualization, M.I., L.G.I. and A.C.; supervision, G.A. and C.D.V.; project administration, G.A. and C.D.V.; funding acquisition, C.D.V. All authors have read and agreed to the published version of the manuscript.

Funding: This research was funded by PSR Campania 2014/2020 Research Project Measure 10-Type of Intervention 10.2.1 - Conservation of indigenous genetic resources to protect biodiversity - Vegetable Genetic Resources-CUP: B24I19000440009.

Data Availability Statement: The data supporting the findings of this study are available from the corresponding authors (Aurora Cirillo, aurora.cirillo@unina.it; Luigi Gennaro Izzo, luigigennaro.izzo@unina.it), upon request.

Acknowledgments: We thank Antonio Bruno and Francesca Mignola for their assistance in field and laboratory activities.

Conflicts of Interest: The authors declare no conflict of interest. 


\section{References}

1. Giorgi, F. Climate change hot-spots. Geophys. Res. Lett. 2006, 33, 1-4. [CrossRef]

2. Giannakopoulos, C.; Le Sager, P.; Bindi, M.; Moriondo, M.; Kostopoulou, E.; Goodess, C.M. Climatic changes and associated impacts in the Mediterranean resulting from a $2{ }^{\circ} \mathrm{C}$ global warming. Glob. Planet. Chang. 2009, 68, 209-224. [CrossRef]

3. Gualdi, S.; Somot, S.; Li, L.; Artale, V.; Adani, M.; Bellucci, A.; Braun, A.; Calmanti, S.; Carillo, A.; Dell'Aquila, A.; et al. The circe simulations: Regional climate change projections with realistic representation of the mediterranean sea. Bull. Am. Meteorol. Soc. 2013, 94, 65-81. [CrossRef]

4. Dell'Aquila, A.; Calmanti, S.; Ruti, P.; Struglia, M.V.; Pisacane, G.; Carillo, A.; Sannino, G. Effects of seasonal cycle fluctuations in an A1B scenario over the Euro-Mediterranean region. Clim. Res. 2012, 52, 135-157. [CrossRef]

5. Arenas-Castro, S.; Gonçalves, J.F.; Moreno, M.; Villar, R. Projected climate changes are expected to decrease the suitability and production of olive varieties in southern Spain. Sci. Total Environ. 2020, 709, 136161. [CrossRef] [PubMed]

6. Benlloch-González, M.; Sánchez-Lucas, R.; Benlloch, M.; Ricardo, F.E. An approach to global warming effects on flowering and fruit set of olive trees growing under field conditions. Sci. Hortic. 2018, 240, 405-410. [CrossRef]

7. Cirillo, A.; Conti, S.; Graziani, G.; El-Nakhel, C.; Rouphael, Y.; Ritieni, A.; Di Vaio, C. Mitigation of High-Temperature Damage by Application of Kaolin and Pinolene on Young Olive Trees (Olea europaea L.): A Preliminary Experiment to Assess Biometric, Eco-Physiological and Nutraceutical Parameters. Agronomy 2021, 11, 1884. [CrossRef]

8. Galán, C.; García-Mozo, H.; Vázquez, L.; Ruiz, L.; De La Guardia, C.D.; Trigo, M.M. Heat requirement for the onset of the Olea europaea L. pollen season in several sites in Andalusia and the effect of the expected future climate change. Int. J. Biometeorol. 2005, 49, 184-188. [CrossRef]

9. Tupper, N. Spanish Olive Oil Under Constant Threat from Climate Change. Available online: https:/ /www.oliveoiltimes.com/ world/spanish-olive-oil-under-constant-threat-from-climate-change/29618 (accessed on 20 December 2021).

10. Ozdemir, Y. Effects of Climate Change on Olive Cultivation and Table Olive and Olive Oil Quality. Horticulture 2016, 60, 65-69.

11. De Micco, V.; Scala, M.; Aronne, G. Effects of simulated microgravity on male gametophyte of Prunus, Pyrus, and Brassica species. Protoplasma 2006, 228, 121-126. [CrossRef]

12. Osborne, C.P.; Chuine, I.; Viner, D.; Woodward, F.I. Olive phenology as a sensitive indicator of future climatic warming in the Mediterranean. Plant Cell Environ. 2000, 23, 701-710. [CrossRef]

13. Moriondo, M.; Stefanini, F.M.; Bindi, M. Reproduction of olive tree habitat suitability for global change impact assessment. Ecol. Modell. 2008, 218, 95-109. [CrossRef]

14. Ponti, L.; Gutierrez, A.P.; Ruti, P.M.; Dell'Aquila, A. Fine-scale ecological and economic assessment of climate change on olive in the Mediterranean Basin reveals winners and losers. Proc. Natl. Acad. Sci. USA 2014, 111, 5598-5603. [CrossRef] [PubMed]

15. Rubio, R.; Balaguer, L.; Manrique, E.; Pérez, M.E.; Vargas, P. On the historical presence of the wild olive [Olea europaea L. var. Sylvestris (Miller): Lehr.(Oleaceae)] in the Eurosiberian region of the Iberian Peninsula. In Anales del Jardin Botánico de Madrid; Consejo Superior de Investigaciones Científicas: Madrid, Spain, 2002; Volume 59, No. 2; pp. 342-344.

16. Olesen, J.E.; Trnka, M.; Kersebaum, K.C.; Skjelvåg, A.O.; Seguin, B.; Peltonen-Sainio, P.; Rossi, F.; Kozyra, J.; Micale, F. Impacts and adaptation of European crop production systems to climate change. Eur. J. Agron. 2011, 34, 96-112. [CrossRef]

17. Poljuha, D.; Sladonja, B.; Šetić, E.; Milotić, A.; Bandelj, D.; Jakše, J.; Javornik, B. DNA fingerprinting of olive varieties in Istria (Croatia) by microsatellite markers. Sci. Hortic. 2008, 115, 223-230. [CrossRef]

18. Ayed, R.B.; Grati-Kamoun, N.; Moreau, F.; Rebaï, A. Comparative study of microsatellite profiles of DNA from oil and leaves of two Tunisian olive cultivars. Eur. Food Res. Technol. 2009, 229, 757-762. [CrossRef]

19. Rallo, P.; Dorado, G.; Martín, A. Development of simple sequence repeats (SSRs) in olive tree (Olea europaea L.). Theor. Appl. Genet. 2000, 101, 984-989. [CrossRef]

20. Marra, F.P.; Caruso, T.; Costa, F.; Di Vaio, C.; Mafrica, R.; Marchese, A. Genetic relationships, structure and parentage simulation among the olive tree (Olea europaea L. subsp. europaea) cultivated in Southern Italy revealed by SSR markers. Tree Genet. Genomes 2013, 9, 961-973. [CrossRef]

21. Di Vaio, C.; Nocerino, S.; Paduano, A.; Sacchi, R. Characterization and evaluation of olive germplasm in southern Italy. J. Sci. Food Agric. 2013, 93, 2458-2462. [CrossRef]

22. Cicatelli, A.; Fortunati, T.; De Feis, I.; Castiglione, S. Oil composition and genetic biodiversity of ancient and new olive (Olea europea L.) varieties and accessions of southern Italy. Plant Sci. 2013, 210, 82-92. [CrossRef]

23. Martin, G.C. Olive flower and fruit production dynamics. Acta. Hortic. 1990, 286, 141-153. [CrossRef]

24. Lavee, S.; Rallo, L.; Rapoport, H.F.; Troncoso, A. The floral biology of the olive: Effect of flower number, type and distribution on fruitset. Sci. Hortic. 1996, 66, 149-158. [CrossRef]

25. Fernández-Escobar, R.; Gomez-Valledor, G.; Rallo, L. Influence of pistil extract and temperature on in vitro pollen germination and pollen tube growth of olive cultivars. J. Hortic. Sci. 1983, 58, 219-227. [CrossRef]

26. Vuletin Selak, G.; Perica, S.; Goreta Ban, S.; Poljak, M. The effect of temperature and genotype on pollen performance in olive (Olea europaea L.). Sci. Hortic. 2013, 156, 38-46. [CrossRef]

27. Biondi, E.; Casavecchia, S.; Pesaresi, S. Nitrophilous and ruderal species as indicators of climate change. Case study from the Italian Adriatic coast. Plant Biosyst. 2012, 146, 134-142. [CrossRef]

28. Aronne, G.; Buonanno, M.; De Micco, V. Reproducing under a warming climate: Long winter flowering and extended flower longevity in the only Mediterranean and maritime Primula. Plant Biol. 2014, 17, 535-544. [CrossRef] [PubMed] 
29. Aronne, G.; De Micco, V.; Scala, M. Effects of relative humidity and temperature conditions on pollen fluorochromatic reaction of Rosmarinus officinalis L. (Lamiaceae). Protoplasma 2006, 228, 127-130. [CrossRef] [PubMed]

30. Mousa, Y.M.; Gerasopoulos, D.; Metzidakis, I.; Kiritsakis, A. Effect of altitude on fruit and oil quality characteristics of "Mastoides" olives. J. Sci. Food Agric. 1996, 71, 345-350. [CrossRef]

31. Kiritsakis, A.; Markakis, P. Olive oil: A review. Adv. Food Res. 1987, 31, 453-482. [PubMed]

32. Ridolfi, M.; Terenziani, S.; Patumi, M.; Fontanazza, G. Characterization of the lipoxygenases in some olive cultivars and determination of their role in volatile compounds formation. J. Agric. Food Chem. 2002, 50, 835-839. [CrossRef] [PubMed]

33. Di Vaio, C.; Nocerino, S.; Paduano, A.; Sacchi, R. Influence of some environmental factors on drupe maturation and olive oil composition. J. Sci. Food Agric. 2013, 93, 1134-1139. [CrossRef]

34. Ledesma, N.A.; Kawabata, S. Responses of two strawberry cultivars to severe high temperature stress at different flower development stages. Sci. Hortic. 2016, 211, 319-327. [CrossRef]

35. Iovane, M.; Aronne, G. High temperatures during microsporogenesis fatally shorten pollen lifespan. Plant Reprod. 2021, in press [CrossRef] [PubMed]

36. Ferri, A.; Giordani, E.; Padula, G.; Bellini, E. In vitro germinability of pollen grains of olive of new genotypes obtained advanced selections. Italus Hortus. 2009, 16, 77-81.

37. Koubouris, G.C.; Metzidakis, I.T.; Vasilakakis, M.D. Impact of temperature on olive (Olea europaea L.) pollen performance in relation to relative humidity and genotype. Environ. Exp. Bot. 2009, 67, 209-214. [CrossRef]

38. Dafni, A. Pollination Ecology: A Practical Approach; Oxford University Press: Oxford, UK, 1992.

39. Dafni, A.; Firmage, D. Pollen viability and longevity: Practical, ecological and evolutionary implications. Plant Syst. Evol. 2000, 222, 113-132. [CrossRef]

40. Rapoport, H.F.; Rallo, L. Postanthesis Flower and Fruit Abscission in Manzanillo'Olive. Am. Soc. Hortic. Sci. 1991, 116, 720-723. [CrossRef]

41. Giorgi, F.; Nielsen, P.; Ozdemir, Y.; Giannakopoulos, C.; Le Sager, P.; Bindi, M.; Moriondo, M.; Kostopoulou, E.; Goodess, C.M Coastal and estuarine processes. Coast. Estuar. Process. 2009, 33, 1-360. [CrossRef]

42. Biesbroek, G.R.; Swart, R.J.; Carter, T.R.; Cowan, C.; Henrichs, T.; Mela, H.; Morecroft, M.D.; Rey, D. Europe adapts to climate change: Comparing National Adaptation Strategies. Glob. Environ. Chang. 2010, 20, 440-450. [CrossRef]

43. Mastrocicco, M.; Busico, G.; Colombani, N. Deciphering interannual temperature variations in springs of the Campania region (Italy). Water 2019, 11, 288. [CrossRef]

44. Smirnova, A.; Leide, J.; Riederer, M. Deficiency in a Very-Long-Chain Fatty Acid-Ketoacyl-Coenzyme A Synthase of Tomato Impairs Microgametogenesis and Causes Floral Organ Fusion. Plant Physiol. 2013, 161, 196-209. [CrossRef]

45. Di Vaio, C. Caratterizzazione morfologica e bio-agronomica delle cultivar campane di olivo. In Il Germoplasma Dell'olivo in Campania; Regione Campania: Napoli, Italy, 2012; pp. 17-26.

46. Fornaciari, M.; Romano, B.; Pieroni, L.; Ciuchi, P. A regression model for the start of the pollen season in Olea eropaea. Grana 1998, 37, 110-113. [CrossRef]

47. Schwartz, M.D. Advancing to full bloom: Planning phenological research for the 21st century. Int. J. Biometeorol. 1999, 42, 113-118 [CrossRef]

48. Orlandi, F.; Bonofiglio, T.; Ruga, L.; Sgromo, C.; Romano, B.; Fornaciari, M. Relationships between vegeta-tive-reproductive phases of plant species and the meteorological variables in a phenological garden of Central Italy. Ital. J. Agrometeorol. Riv. Ital. Agrometeorol. 2010, 15, 35-43.

49. Orlandi, F.; Ruga, L.; Romano, B.; Fornaciari, M. Olive flowering as an indicator of local climatic changes. Theor. Appl. Climatol. 2005, 81, 169-176. [CrossRef]

50. Bonofiglio, T.; Orlandi, F.; Sgromo, C.; Romano, B.; Fornaciari, M. Influence of temperature and rainfall on timing of olive (Olea europaea) flowering in Southern Italy. N. Z. J. Crop Hortic. Sci. 2008, 36, 59-69. [CrossRef]

51. Montemurro, C.; Dambruoso, G.; Bottalico, G.; Sabetta, W. Self-incompatibility assessment of some italian olive genotypes (Olea europaea L.) and cross-derived seedling selection by ssr markers on seed endosperms. Front. Plant Sci. 2019, 10, 1-13. [CrossRef]

52. Wu, S.B.; Collins, G.; Sedgley, M. Sexual compatibility within and between olive cultivars. J. Hortic. Sci. Biotechnol. 2002, 77, 665-673. [CrossRef]

53. Ferrara, G.; Camposeo, S.; Palasciano, M.; Godini, A. Production of total and stainable pollen grains in Olea europaea L. Grana 2007, 46, 85-90. [CrossRef]

54. Aguilera, F.; Ruiz Valenzuela, L. Time trend in the viability of pollen grains in the Picual olive (Olea europaea L.) cultivar. Palynology 2013, 37, 28-34. [CrossRef]

55. Marchese, A.; Marra, F.P.; Costa, F.; Quartararo, A.; Fretto, S.; Caruso, T. An investigation of the self- and inter-incompatibility of the olive cultivars "Arbequina" and "Koroneiki" in the Mediterranean climate of Sicily. Aust. J. Crop Sci. 2016, 10, 88-93.

56. Pacini, E.; Dolferus, R. Pollen developmental arrest: Maintaining pollen fertility in a world with a changing climate. Front. Plant Sci. 2019, 10, 1-15. [CrossRef] [PubMed]

57. Firon, N.; Nepi, M.; Pacini, E. Water status and associated processes mark critical stages in pollen development and functioning Ann. Bot. 2012, 109, 1201-1213. [CrossRef]

58. Heslop-Harrison, J. An Interpretation of the Hydrodynamics of Pollen. Am. J. Bot. 1979, 66, 737-743. [CrossRef] 
59. Franchi, G.G.; Nepi, M.; Dafni, A.; Pacini, E. Partially hydrated pollen: Taxonomic distribution, ecological and evolutionary significance. Plant Syst. Evol. 2002, 234, 211-227. [CrossRef]

60. Aylor, D.E.; Baltazar, B.M.; Schoper, J.B. Some physical properties of teosinte (Zea mays subsp. parviglumis) pollen. J. Exp. Bot. 2005, 56, 2401-2407. [CrossRef] [PubMed]

61. Buitink, J.; Leprince, O. Glass formation in plant anhydrobiotes: Survival in the dry state. Cryobiology 2004, 48, 215-228. [CrossRef]

62. Kravets, E.A. Cytomixis and its role in the regulation of plant fertility. Russ. J. Dev. Biol. 2013, 44, 113-128. [CrossRef]

63. Hinojosa, L.; Matanguihan, J.B.; Murphy, K.M. Effect of high temperature on pollen morphology, plant growth and seed yield in quinoa (Chenopodium quinoa Willd.). J. Agron. Crop Sci. 2019, 205, 33-45. [CrossRef]

64. Kotak, S.; Larkindale, J.; Lee, U.; von Koskull-Döring, P.; Vierling, E.; Scharf, K.D. Complexity of the heat stress response in plants. Curr. Opin. Plant Biol. 2007, 10, 310-316. [CrossRef]

65. Larkindale, J.; Vierling, E. Core genome responses involved in acclimation to high temperature. Plant Physiol. 2008, 146, 748-761. [CrossRef]

66. Scharf, K.D.; Berberich, T.; Ebersberger, I.; Nover, L. The plant heat stress transcription factor (Hsf) family: Structure, function and evolution. Biochim. Biophys. Acta (BBA)-Gene Regul. Mech. 2012, 1819, 104-119. [CrossRef] [PubMed]

67. AL-Quraan, N.A.; Locy, R.D.; Singh, N.K.; Sun, W.; Montagu, M.; Van Verbruggen, N. Small heat shock proteins and stress toler. Plant Physiol. Biochem. 2002, 1577, 1-9.

68. Hong, S.W.; Vierling, E. Mutants of Arabidopsis thaliana defective in the acquisition of tolerance to high temperature stress. Proc. Natl. Acad. Sci. USA 2000, 97, 4392-4397. [CrossRef] [PubMed]

69. Assab, E.; Rampino, P.; Mita, G.; Perrotta, C. Heat shock response in olive (Olea europaea L.) twigs: Identification and analysis of a cDNA coding a class I small heat shock protein. Plant Biosyst. 2011, 145, 419-425. [CrossRef] 